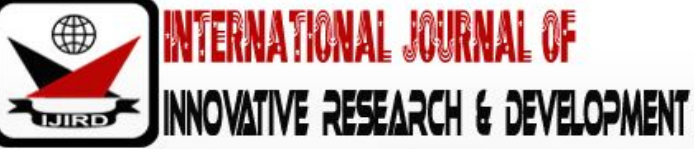

ISSN 2278 - 0211 (Online)

\section{Effectiveness of Levels of Implementation of School Evaluation in Arusha City Public Secondary Schools, Tanzania}

\author{
Efraim N. M. Kosia \\ Ph.D. Candidate, Mwenge Catholic University, Tanzania \\ Dr. Evans Ogoti Okendo \\ Faculty of Education, Mwenge Catholic University, Tanzania
}

\begin{abstract}
:
This study aimed at assessing the Effectiveness of School Evaluation on Improving Teaching and Learning Processes in Arusha City Public Secondary Schools. This study was guided by the Utilization Focused Evaluation theory which assume the regardless how the evaluation processes and findings are, unless they are implemented to bring improvement, the evaluation is in vein. The study employed convergent parallel mixed methods through concurrent approach where Ex-post Facto design case study designs were employed. The study sample were 166 teachers, 3 Heads of schools, 3 Ward Education Officers, 1 City Academic Officer, 6 School Quality Assurance Officers (SQAOs) and 1 Chief Zonal Quality Assurance Officer. Both probability and non-probability sampling procedures were utilized in selecting participants of the study. The study utilized questionnaires, interview guides and focused group discussion for data collection. Internal consistency reliability was estimated based on correlations among all Likert scale items on a questionnaire test using coefficient Alpha method. The study found that high performing schools implement SQAOs' findings schools than low and treatment schools. However, SQAOs' visit does not reflect the true picture in low performing schools as compared to both high performing and Treatment schools because of the unintended effects. The study recommends the true experiment design research that involves more low and high performing schools.
\end{abstract}

Keywords: External evaluation features, intended and unintended effects

\section{Introduction}

Over the years, in Tanzania like many other countries, school external evaluation (SEE) in form of school inspection has been used as a principal mechanism of monitoring the delivery of education, adhering to the specified curriculum and established standards as well as ensuring that there is an effective improvement in schools. School inspection has been considered as an external evaluation where an evaluation of the school is carried out by school inspectors. School inspection is distinguished from internal forms of evaluation where members of school carry out the evaluation of their school.

School external evaluation as an evaluation process, is a systematic collection, analysis and interpretation of evidence leading, as part of the progression of judgement of value with a view of taking action. External evaluation in most cases, focus more strongly on accountability dimension while on the other side it aims at giving feedback for the purpose of school improvement. According to Organization for Economic Cooperation and Development (OECD, 2013), SEE is considered as a review of the quality of education as it is judged by an external body or institutions. In this regard, school inspectors would be expected to assess, monitor and evaluate quality of school teaching and learning as well as assessing organization, management and environment of the school (United Republic of Tanzania (URT), 2011).

However, most of the judgments of SEE decisions are based on figures and documents, rather than getting enough time to interact with teachers and heads of schools through interview or observation. Inspectors tend to focus on measurable results rather than complex realities of the school processes. School inspectors exhibit a mix-up of adaption, doubt, imagination, and professional judgment in line with their study background. Thus, school inspectors struggle with their judgments and seek to somehow to merge programmatic and technical elements within the complexity of school realities (Lindgren, 2015), which may need involvement of classroom teachers in the processes of evaluating the schools. Thus, effective school evaluation mechanism would need to create dialogue between evaluation subject and evaluators for the sake of mutual understanding of school situation.

In various countries, including Tanzania, school inspectors spend days at school to conduct classroom observation where they assess classroom climate, teacher's mastery of subject content and teaching methodology where they are expected to discuss with the individual teachers on how the taught lesson could be improved. During the classroom observation, school inspectors usually focus on subject content, teaching learning methods, teaching aids and classroom control. School inspectors would facilitate school improvement on areas of teaching by giving feedback and advice to 
teachers after classroom observation. However, it has been observed that school inspectors do not get enough time to discuss the inspection findings with teachers compared to the head of schools (Haule, 2012). On the other side, in Tanzania, it has been observed that teachers in various schools tend to be dissatisfied with the school inspections exercise and its findings and recommendations. This scenario leaves the whole exercise on the cross road as far as the purpose of school inspection is concerned.

The history of school inspection system in Tanzania can be traced back based on two major categories; the school inspection system before independence and school inspection after inspection. In the former system, teachers felt that school inspection had intention of threatening them where as the later emphasized on assisting teachers to perform their duties (URT, 2006).

School inspection system in Tanzania during colonial period had the aim of serving colonial interests and appeared to be threatening to teachers which can be grouped in four subcategories as school inspection system in 1903 1918, School inspection system in 1919 - 1925, School inspection system in 1925 - 1945 and School inspection system in 1946 - 1961. The purpose of colonial education was for them to get staff who would work as clerical worker rather than getting personnel who would excel and exercise their full innovative potential. According to URT (2006), school inspection in Tanzania (former Tanganyika), started during the Germany colonial regime in which education regulations were used to provide control for the people to have discipline, to be smart and work hard maintaining culture and tradition for the benefits and interests of the Germany. The use of circular in operationalization of inspection during this period made the system so weak in implementation of the inspection activities compared to later inspection systems which started during the British rule for the period from 1919 to 1961.

From 1919 to 1925 school inspectors used one curriculum in their inspection to address problems that faced schools in which the discipline issues were dealt at school, district and regional levels. In this regard, schools' inspectors had judgmental mandate to promote, transfer, demote and even suspend teachers from employment but in 1922 the Director of Education was recruited at the Ministry of Education; the decision which assumed that the African Teachers would work better under supervision (URT, 2006).

In 1925, the Department of Education in Tanganyika introduced three groups of school inspectors which were: Education secretaries and organization supervisors who had responsibility of inspecting school of voluntary organization whereas public school supervisors had the responsibility of inspecting governmental schools and regional government.

The period between 1946 - 1961 school inspections was more strengthened and formalized where in 1952, the 10 years development plan of 1946 - 1956 was establishes with the appointment of the first chief inspector of schools and official recognition of other schools' inspectors. In other five years development plan which started from 1957 - 1961, the appointment of Deputy Education Secretaries to inspect schools under volunteering institutions and primary schools' inspectors were made.

The reform of School Inspectorate after 1961 when Tanganyika got its independence intended to change the perspectives where teachers felt being threatened by colonial regime and support teachers and other stake holders (URT, 2006) to execute their responsibility in bringing improvement of education standards. Subsequently, it was during this period when the government had initiatives of introducing various educational acts for the purpose improving the quality of Education (URT, 2006). The Education Act No. 37 of 1961 abolished racial discrimination in the provision of education by streamlining the curriculum, examinations as well as the financing of education to be provided in uniformity where the Deputy Educational Officer was appointed to be responsible with school inspection and primary school inspectors were appointed to handle inspection at primary school level. In 1970, in response to the Education Act No. 50 of 1969 which empowered the government to take ownership of voluntary schools, more primary school inspectors were recruited and frozen voluntary schools' inspectors. Inspection of all secondary schools and teachers' colleges were held by inspector at the head quarter of Ministry of Education. Subsequently, as a result of Act No. 27 of 1972 on decentralization of power at regional level, the Deputy Director of Education (DDE) responsible for the Curricula and Examination had to report to the Director of Education. In this system; primary school, secondary school and teachers' college inspection departments were established under the DDE.

Section 41 of the Education Act No. 25 of 1978 gave mandate for the Commissioner of Education to ensure that every school in Tanzania is inspected according to the rules and orders. In its implementation, the Chief Inspector Officer under the Education Commissioner's Officer, currently known as the Chief Education Officer was appointed at Ministry level with four Departments (for Primary school, Secondary school, Teachers colleges and administration), Zonal Chief Inspectors of schools were appointed to handle secondary schools and teachers colleges inspection, and District Chief Inspectors to handle inspection at pre-primary, primary and adult education levels, the system which has existed to date.

From 2010 to 2015 documents to emphasize the use of school self-evaluation as an integral part of school inspection were released as efforts of facilitating the implementation of school inspection finding and recommendation to bring intended improvement in schools. According to the School inspection handbook for School inspectors of 2010, in order to make school inspection successful, it is the duty of head of schools to complete School Evaluation Form (SEF) as early as possible and send it back to the District/ Zonal Chief inspector. However, handbook does not specify how early schools are expected to submit the forms, the loophole which is likely to result on inconsistency on the time when schools submit the forms. Also, the whole school inspection handbook which was released at the time the inspectors' handbook was issue was not accompanied with the checklist for school self-evaluation which would facilitate schools to execute their duty. The SEF which is usually issued to schools had not been published in the inspection booklets something that might reduce its value compared to the other inspection guidelines. Simultaneously in 2011, the government released 'School Supervisors' Training Manual which stipulated that school supervisions were to be conducted at Ministerial, Regional, Local 
Government, Ward and the school's levels (URT, 2011) using the Guidelines for School Supervision (URT, 2010) as an effort of the government to devolve power to the grassroots level.

In April 2016, a circular was released (URT, 2016) in which in 2 secondary schools in each district and 2 primary schools in each district had to be involved in implementation of pilot study of school quality assurance. According to the circular document, the School Inspectorate Department has been changed to be called Quality Assurance Department. In this transformation, Quality assurer agrees that assurance of quality is a complex and difficult task which is better understood by teachers; which is in controversy to school inspectors' perspectives. Therefore, quality assurers are expected to provide support for schools to put strategies in place and monitor the progress of implementation evaluation findings to make right things happen in the spirit of collaboration.

\subsection{Statement of the Problem}

Schools in Tanzania depend on evaluation conducted by the school quality Assurance Officers, which only targets $50 \%$ of total population of schools in the country but even where the external evaluations are held, teachers are not given sufficient opportunity to express themselves and provide their inputs for the school external quality assurer to understand and provided advices and appropriate recommendations which are based on the existing complex circumstances in the schools. Consequently, the situation has resulted to inadequate implementation of quality assurers' recommendations and subsequently, expected improvement as a result of inspection is not achieved in schools. The government view that the value for money is not achieved because school inspection has not resulted in improvement in schools (URT, 2008) whereas schools, feel that school inspection operates in a way that threaten their democracy and professionalism (Haule, 2012), something that makes the schools to create artificial impression and appearance to be assessed more positively by hiding the reality in class rooms, presenting wrong documents, choosing to teach simple topic during inspection, repeating the topics which were previously taught or not trust the feedback given by school inspectors. These effects have created negative influences on school effectiveness and there seems to be no promising adequate results of school evaluation on achieving its goal for improving and maintaining quality of education.

School evaluation existing as catalyst could enlighten school members to have broader view of their school in comparison to other schools. Studies has shown that unless schools develop the capacity to diagnose their own problems and improve standards through internal mechanisms the impact of external evaluators like school inspection can be severely limited (Nayir \& McNamara, 2013). Therefore, designing school self-evaluation modality that optimized school external evaluation would result to positive schools' intended effects on teaching which is the core role of teachers and would facilitate students' learning processes. According to Ehren, Gustafsson, Altrichter, Skedsmo, Kemethofer, and Huber (2015), studies on the complex and interrelated mechanisms of the impact of school inspections suggests that school inspection models can be improved when policy makers develop models that impact on the teaching level through an evaluation of, and feedback about, the quality of teaching and in consideration of broader mechanisms of impact through norm-setting and dissemination of good school practice.

\subsection{Research Questions}

- What are the levels of intended effects of school external evaluation in Arusha City Public secondary schools?

- What are the levels of unintended effects of school external evaluation in Arusha City Public secondary schools?

\subsection{Hypothesis}

- There is no significant difference in the levels of means scores of implementations of SQAOs' findings and recommendations of school external evaluation findings between different schools.

- There is no significant difference in the levels of unintended effects of school external evaluation in different schools?

\subsection{Conceptual Framework}

School Quality Assurance Officers (SQAOs) in Tanzania visits schools for the purpose of inspecting, advising and supporting schools. They are supposed to conduct classroom observation and give oral feedback to individual teachers, they assess schools' administration and they also assess, whether the schools' environment is conducive for effective teaching and learning process to take place.

In the presented conceptual framework, the model has three quality assurance features namely: School external evaluation features comprising of communication styles, inspection feedback and setting expectation; school features comprising of school self-evaluation and school improvement capacity; and intended/ unintended effects on teaching and learning. The external quality assurance system framework assumes that the quality assurance guidelines/ standards are key aspects in setting expectations of inspection whereas communication styles and quality of feedback influences the extent to which the user of inspection finding accept and use the external quality assurance findings and recommendations.

After inspection, SQAOs are expected to discuss the findings with individual teachers observed during classroom observations, the school leadership and later, they hold a meeting with all teachers to give them the overall feedback of school inspection visit. During the exit meeting with all teachers, the proposed conceptual model assumes that school inspectors should state clearly the expected performance standards which are measurable and realistic. School inspectors are expected to write a report within two weeks which is returned to school and copies sent to different stakeholders including District Education Officer who have supervisory responsibilities at the district level. 
Setting expectations and accepting feedback are the immediate outcome of external quality assurer but at the same time the catalyst for schools to undertake School Self-evaluation which leads to them taking development actions. During the school self-evaluation, schools engage themselves into systematic review and reflection about the quality of their school as a step towards undertaking school improvement actions. It is assumed that school improvement action may lead to intended and unintended effects in teaching and learning and improvement capacity of the school community. The conceptual model also assumed that, SQAOs' feedback is an important tool that could stimulate and broaden the focus of school self-evaluation (Vanhoof \& Petegem, 2007). The outcome of school self-evaluation is an operational plan which details improvement process where schools addresses issues and recommendation of inspection findings and other key emanating from internal evaluation. The action plan is expected to explain actions that should be done with clear elaboration on who should do what, when and how, and indicate all internal and external resources required to bring intended effects in the schools.

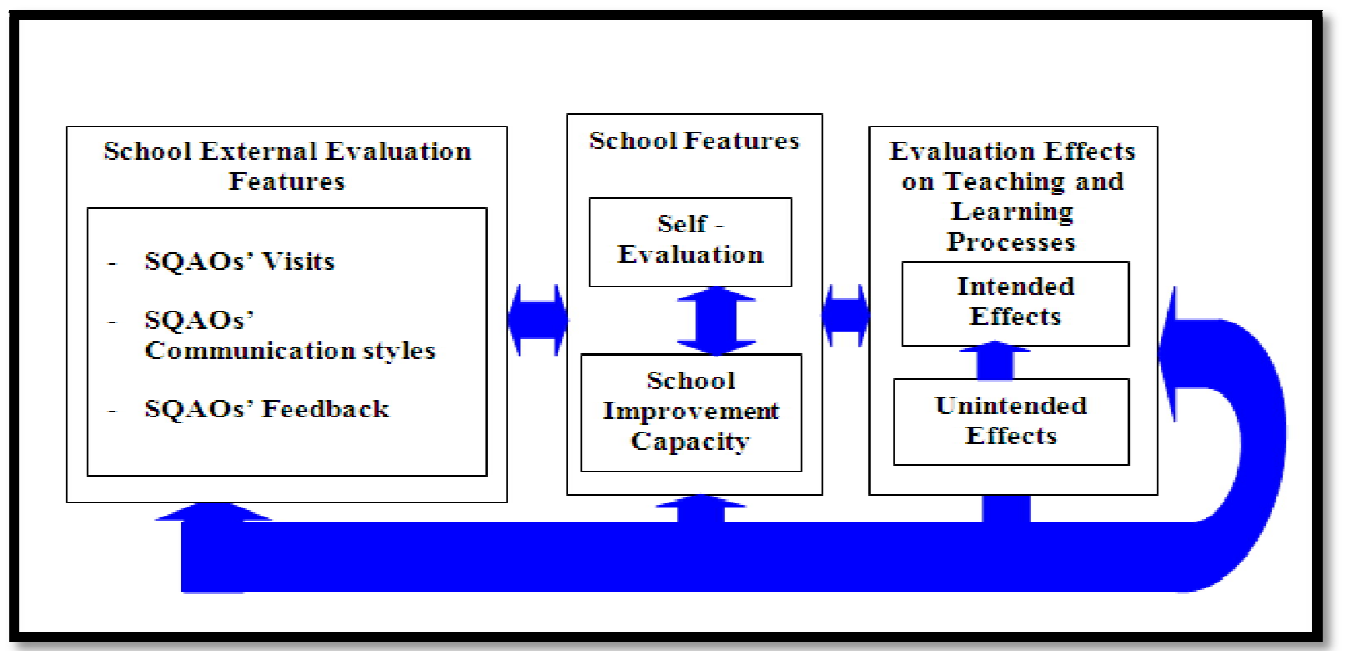

Figure 1: Intended and Unintended Effects of School External Evaluation (Inspections)

According to this model, schools are expected to act on the expectations and use the inspection feedback when conducting self-evaluations and taking school improvement actions. Stakeholders are also expected to use the inspection standards and report of the school's functioning against these standards to take actions that will motivate the schools to improve. Self-evaluations by schools are expected to build their capacity to improve that will lead to more effective teaching and learning conditions. Similarly, improvement actions will when successfully implemented lead to more effective school and teaching conditions. The conditions are expected to results into long term high student achievement which are not included in the study.

\section{Literature Review}

\subsection{Implementation of External Evaluation Findings and Recommendations}

External evaluation is used to mean the review and reporting on a school's work by people who are not parts of the school's organization. The external evaluators may belong to different agencies and may come with different mandates in the school. In some countries, like UK, local authority personnel, inspectors and advisers; play a role in reviewing school performance, with varying combinations of audit and support, feedback and advice (MacBeath \& McGlynn, 2005).

\subsubsection{Levels of Effects of Inspection in Schools}

The modality and degree to which different countries make of inspection reports available to education stakeholder do vary. In English, Irish, and Dutch inspectorate's system do publish reports but, in the Netherlands, school inspectorate goes a step further by handing over to the public the lists of failing schools and summaries of the inspection assessments of all schools for the purpose of creating awareness on school's status. The country like Austria, reports are only availed to the local authority whereas the country like Swiss even municipal authorities receive anonymized reports so that they do not know single school results but it is the responsibility of the schools which are given an individualized report to inform the school governing bodies, parents, and so forth about the inspection feedback. It is assumed that accountability pressure is higher in systems which publish inspection reports on individual schools to the general public (Altrichter \& Kemethofer, 2015).

School inspection as external evaluation in UK, the key mechanisms that reinforce Ofsted's promotion of school improvement are the setting of standards, giving school feedback, the use of sanctions and rewards, the collection of information on schools and public accountability (Jones \& Tymms, 2014). Ehren (2015) found that mechanism of effective school inspection should have clear school inspections expectations, inspection feedback, capacity building and stakeholder involvement. The school that is likely to exhibit improvement is characterized by its capacity to accept and use inspection feedback, setting expectations around standards and methods inspections, executing capacity building as means of enhancing professional learning of its teachers as well as engaging stakeholders to effectively implement improvements. 
School inspection driven by allegations of irregularities in use of resources, need to check construction of buildings and related utilities, and allegations of misconduct by teachers and/ or students but it fails to prioritize quality of instruction and poor performance of students in the inspection cycle (Uwazi, 2009) cannot bring improvement in teaching and learning environment. According to Uwazi (2009), inadequate monitoring and evaluation as a part and parcel of the learning process about what works or doesn't and for improvement of future inspections is likely to result into wastage of useful public resources and time, and failure to safeguard quality of instruction and bring intended improvement in schools.

The effects of inspection can be distinguished based on different types feedback based on whether they are conceptual, instrumental, symbolic, their impact on personal and collective self-efficacy or impact on pupils' learning outcomes whereas three kinds of undesirable side effects may be intended strategic behavior, unintended strategic behavior and emotional impact on school staff members (Penninckx, 2017).

The conceptual effect of school inspection consists of the inspection's impact on the mutual understanding through reflection of teachers and other staff members in schools. School inspectors are expected to hold a discussion with individual teachers after class observations to provide them with an analysis of their strengths and weaknesses, and reflect on the quality of their teaching and learning processes. It is assumed that in course of the reflection process, teachers would not only have new conception of processes but the dialogue with inspector would also leads to concrete ideas for further development of which at this point, school inspection act as an instrument of gaining knowledge about their teaching and learning processes (Gaertner, Wurster and Pant (2014).

Most of the research base on inspections has focuses on the instrumental effects on schools where teachers observed in the classrooms are expected to act on the views provided, and the expectations set by the inspection, and to use the inspection feedback for engaging in improvement actions in their schools. Instrumental use of school inspection achieved when the decisions are made as a result of inspection and subsequently, actions are taken that based upon the decisions. However, the knowledge acquired from school inspection is only rarely used for autonomous school improvement (Gaertner et al., 2014).

Symbolic of inspection use explains the extent to which the school inspection report is treated as an opportunity to convince others of viewpoints that already existed prior to the inspection or to legitimize an opinion already held in a school with the viewpoints of taking actions that contribute to school development. In this perspective, school inspection report is used as management and improvement motivation tool especially where staffs have not accepted the reality about the quality of their teaching and learning process even in a situation where school self-evaluation is implemented. Another effect of school inspection is an impact on personal and collective self-efficacy where teachers' personal selfefficacy is the beliefs teachers hold that they can positively influence student learning as opposed to the collective selfefficacy where school's shared belief in its conjoint capabilities to organize and execute the courses of action required to produce given levels of students' attainments (Penninckx, 2017). The fifth inspection effect according to Penninckx (2017) is effect on pupils' learning outcomes which observed as impact of the inspection on the learning results of pupils.

\subsubsection{Levels of Unintended Effects as Challenges of School Inspections}

Unintended occur when school spare time prepare for inspection which may drive teachers away from normal routine like lesson planning, preparation and teaching in order to meet the school's inspectors' expectations. Mcrone, Rudd, Blenkinsop, Wade, Rutt and Yeshanew (2006) defines unintended strategic as "an interruption from normal school life and normal school development because of the notification, conduct or findings of inspection where before the inspection, staff members in schools may neglect their primary tasks, and postpone or even omit their own priorities in favour of preparing for the inspection". According to McCrone et al. (2006), some head of schools and teachers increase attention for actions related to inspection recommendations after inspection something that may lead to a decrease in attention being paid to other areas.

Intended strategic behavior is the situation where teachers intentionally providing a better picture of the school with the purpose of receiving a more favorable inspection judgement. These intended strategic behaviour includes extra preparation and intentional adaptations by teachers both prior to and during the inspection with the aim of providing a better image of the school or even to mislead the inspectors but they seldom do these activities really contribute to school improvement (Penninckx, 2017). Window dressing which is sometimes known as playing the game refer to the creation of proactive and reactive arrangements, which are generated simply and solely to be assessed more favourably by the supervisor (De Wolf \& Janssens, 2007).

The head of schools who have negative attitude with teachers may use school inspection results to threaten educators which may create an impression that school external evaluation is there to punish teacher who do not do their work effectively. Studies has revealed that some teachers confirmed that most principals used whole-school evaluation to threaten them if things were not going well in their school, as a result by the time the external evaluators come to the school to conduct the whole-school evaluation teachers had already developed a negative attitude towards the external evaluators (Mazibuko, 2007). In School inspection system where inspectors provided notice for inspection visit, it was found that it enables the teachers concerned to prepare adequately for the observation lessons. The preparation prior to inspection, enables teachers to arm themselves with all the teaching and learning materials they can possibly use at a time and sometimes, rehearse even the lessons they intend to teach for the exercise (Opoku-Asare, 2006).

Emotional effect occurs when staff members' experience emotional upsets as a result of the inspection. According to Penninckx (2017), most researches have focused on stress and anxiety but other effects which have been documented include anger, apprehensiveness, conflict, disillusion, frustration, grief, guilt, irritability, loss of job satisfaction, tiredness, resentment, sleeplessness, worthlessness and depression. 
In Tanzania, school leaders reported that school inspections have been politicized, meaning that some school inspectors follow what politicians demand in the education system to achieve their political goals both school teachers and leaders perceive that school inspections look like routine practices and interfere with school programmes and waste resources and school teachers', leaders and students' time (Haule, 2012)

\section{Methodology}

The study utilized convergent parallel mixed methods design through concurrent approach. The study involved the collection of both qualitative and quantitative data in response to research questions and hypotheses, the analysis of both forms of data and then merging the data to come up with conclusion and recommendation of the study (Creswell, 2014). Merging the data in this study involved combining the quantitative and qualitative data through the procedures of a side-by-side comparison, data transformation and finally a joint display of the results from the two databases to show how the data convergent. The target population of the study was 949, comprising of 894 classroom teachers and 26 Head master/ mistress, 19 Ward Education Officers and 20 North-west School Quality Assurance Zone Officers. The researchers collected data from the ongoing pilot study on implementation of school quality assurance where school inspectors were shifting from the role of quality controller to quality assurers. In this regard, school quality assurance officers had a role of creating conditions that would allow schools to execute self-evaluation activities using internal quality assurance approach whereas, so called inspectorate would play a role as external quality assurers. Other schools were sampled using both probability and non-probability sampling procedures for the purpose of comparing with the schools under the pilot study in the Arusha City. The study utilized questionnaires, interview guides and focused group discussion for data collection.

\section{Results}

4.1. Levels of Implementation of School Evaluation Findings and Recommendations on Teaching and Learning Processes in All Schools

The intention of this section was to establish the extent to which schools implement specific recommendations from SQAOs. Usually, SQAOs give comments on what teachers should improve after each class observation. The extents to which the comments in terms of findings and recommendations from the SQAOs' are implemented reflect the improvement in teaching and learning processes.

In order to understand levels of implementation, researcher organized 12 items which measured various comments on areas to improve as given by SQAOs. The extent to which schools were still implementing the recommendations from the SQAOs were assessed using five Likert scale where teachers were required to show the extent to which they were still implementing the comments given during SQAOs' visits. In the Likert scale, strongly agreed meant very high implementation whereas, strongly disagree meant very low degree of implementation of recommendations and findings given as comments to teachers on what to improve. Subsequently, item means of responses were computed when schools were nested together, at low and high performing schools as well as means for treatment school. The overall levels showing the degrees of implementation were established from teachers' questionnaire which revealed the extent of implementation in each school category.

Results of levels of implementation of the findings and recommendations of SQAOs given as comments during school visit are presented in Table 1. Show means when all schools were nested together, low performing schools, high performing schools and treatment school.

\begin{tabular}{|c|c|c|c|c|c|}
\hline S/ N & Items & \multicolumn{4}{|c|}{ Schools Category } \\
\cline { 3 - 6 } & $\begin{array}{c}\text { All } \\
(\mathrm{N}=166)\end{array}$ & $\begin{array}{c}\text { Low Performing } \\
(\mathrm{n}=48)\end{array}$ & $\begin{array}{c}\text { High Performing } \\
(\mathrm{n}=98)\end{array}$ & $\begin{array}{c}\text { Treatment } \\
\text { Performing }(\mathrm{n}=20)\end{array}$ \\
\hline 1 & $\begin{array}{c}\text { I have improved on } \\
\text { how to use the } \\
\text { syllabi's in } \\
\text { preparation of scheme } \\
\text { of work }\end{array}$ & 3.55 & 3.52 & 3.62 & 3.30 \\
\hline 2 & $\begin{array}{c}\text { I have improved on } \\
\text { how to prepare lesson } \\
\text { plan }\end{array}$ & 3.61 & 3.48 & 3.74 & 3.25 \\
\hline 3 & $\begin{array}{c}\text { I have improved on } \\
\text { how use Teaching and } \\
\text { Learning methods }\end{array}$ & 3.54 & 3.44 & 3.63 & 3.15 \\
\hline 4 & $\begin{array}{c}\text { I have improved on } \\
\text { how to prepare and } \\
\text { use of } \\
\text { teaching/ learning aids } \\
\text { in teaching }\end{array}$ & 3.49 & 3.40 & & 3.30 \\
\hline 5 & $\begin{array}{c}\text { I have improved my } \\
\text { methods that I use to } \\
\text { assess of my pupils }\end{array}$ & 3.48 & 3.38 & & \\
\hline
\end{tabular}




\begin{tabular}{|c|c|c|c|c|c|}
\hline \multirow[t]{2}{*}{$\mathbf{S} / \mathbf{N}$} & \multirow[t]{2}{*}{ Items } & \multicolumn{4}{|c|}{ Schools Category } \\
\hline & & $\begin{array}{c}\text { All } \\
(\mathrm{N}=166)\end{array}$ & $\begin{array}{l}\text { Low Performing } \\
\quad(\mathrm{n}=48)\end{array}$ & $\begin{array}{l}\text { High Performing } \\
(\mathrm{n}=98)\end{array}$ & $\begin{array}{c}\text { Treatment } \\
\text { Performing }(n=20)\end{array}$ \\
\hline 6 & $\begin{array}{l}\text { I have improved the } \\
\text { quality of pupils' notes }\end{array}$ & 3.46 & 3.35 & 3.56 & 3.25 \\
\hline 7 & $\begin{array}{l}\text { I spend more time in } \\
\text { teaching my subjects }\end{array}$ & 3.57 & 3.48 & 3.63 & 3.50 \\
\hline 8 & $\begin{array}{l}\text { I have improved my } \\
\text { teaching Strategies to } \\
\text { ensure logical } \\
\text { coverage of topics in } \\
\text { the syllabus }\end{array}$ & 3.55 & 3.46 & 3.64 & 3.30 \\
\hline 9 & $\begin{array}{l}\text { I have made } \\
\text { improvement to } \\
\text { ensure that pupils' get } \\
\text { more opportunity to } \\
\text { learn }\end{array}$ & 3.56 & 3.50 & 3.62 & 3.40 \\
\hline 10 & $\begin{array}{l}\text { I have improved the } \\
\text { way I use assessments } \\
\text { to improve pupils' } \\
\text { learning }\end{array}$ & 3.50 & 3.34 & 3.65 & 3.15 \\
\hline 11 & $\begin{array}{l}\text { I have improved my } \\
\text { teaching to ensure } \\
\text { Clear and structured } \\
\text { teaching of my pupils }\end{array}$ & 3.48 & 3.37 & 3.55 & 3.40 \\
\hline 12 & $\begin{array}{l}\text { The quality of self- } \\
\text { evaluations/ internal } \\
\text { quality assurance in } \\
\text { the school has } \\
\text { improved }\end{array}$ & 3.46 & 3.42 & 3.52 & 3.25 \\
\hline & $\begin{array}{c}\text { Overall } \\
\text { implementation }\end{array}$ & 3.52 & 3.43 & 3.61 & 3.30 \\
\hline
\end{tabular}

Table 1: Levels of Means of the Implementation of School Evaluation Findings and Recommendations at Item Level Note: Level of Implementation is Very Low When $1 \leq \mathrm{M}<2$, Low When $2 \leq \mathrm{M}<3$, Moderate When $M=3$, High When $3<M \geq 4$ and Very High When $M>4$

Results presented in Table 1. Show that levels of implementation of all findings and recommendations on teaching and learning from SQAOs were found to be high $(3<M \geq 4)$. Similarly, the overall implementation of the teaching and learning recommendations in all school categories, including when all schools were nested together was found to high. When all schools were nested together, the highest implementation level was found on the extent to which schools improved their preparation of lesson plans $(\mathrm{M}=3.61)$ but lowest improvement was found on the extent to which schools improved both quality of pupils' notes ( $M=3.46)$ and quality of self-evaluations ( $M=3.46)$ in their schools.

In low performing schools, teachers had highest improvement $(\mathrm{M}=3.5)$ on the use of syllabi's in preparation of scheme of work and lowest improvement $(\mathrm{M}=3.34)$ on the use of assessments to improve pupils' learning. This may imply that low performing school had highest improvement on preparing a clear and accurate course scheme of work which might make explicit what the student were expected to do during the school calendar including assessments, delivery of content as well as timely preparation of teaching and learning materials.

In high performing schools, like when all schools were clustered together, result on highest and lowest implementation was found on improvement of how schools prepared lesson plans $(\mathrm{M}=3.74)$ and quality of self-evaluations (M=3.5), respectively. These results may indicate that teachers improved their skills on how clearly direction of what kind of materials of study to be taught and how to teach them. In this regard, teachers could have a written description of teaching process showing the details description of materials, methods, time and the place of implementation of teaching and learning process as well as methods to be used for evaluating students.

Though the High performing schools showed lowest improvement on quality of self-evaluations, it is worth noting that these schools had highest value $(\mathrm{M}=3.5)$ on the improvement of quality of school self-evaluation compared to Low Performing $(\mathrm{M}=3.42)$ and Treatment schools $(\mathrm{M}=3.25)$. These results indicated that the High performing schools might have high potential to execute school self-evaluation than low performing schools.

Treatment school showed highest implementation on time spent in teaching the syllabus of the subjects taught by the individual teachers $(\mathrm{M}=3.5)$ and lowest level of implementation on both improvement of how to prepare and use teaching/ learning aids in teaching $(\mathrm{M}=3.15)$ as well as improvement on the way of using assessments as tools of improving pupils learning $(\mathrm{M}=3.15)$.

Results presented in Table 1. Show that the overall level of implementation of findings and recommendations from SQAOs were found to be high. Generally, the high implementation of all findings and recommendations was reflected by all mean values falling within high level $(\mathrm{M}>3)$. The highest implementation level was found in High performing schools 
$(\mathrm{M}=3.61)$ and surprisingly, the lowest implementation of findings and recommendations from SQAOs was found in Treatment school $(\mathrm{M}=3.30)$. These results show that the school that had received a support from SQAOs on how to implement school self-evaluation assessed themselves as lowest on the level to which they took actions towards implementing the teaching and learning findings and recommendations from SQAOs. One would have expected to experience highest implementation in Treatment school because this school had received school self-evaluation support from school SQAOs. However, this result may be due to the reason that school itself might have identified through internal school quality assurance mechanisms and solved most of the teaching and learning addressed weakness before the SQAOs' visit which might have led to much few recommendations from SQAOs.

Similar results were found during interviewee of head of schools and focus group discussion of teachers. Though teachers and head of schools viewed that school evaluation had led to high implementation of the findings and recommendations from the SQAOs, they argued that the high number of students in relation to the number of students has made teacher fail to achieve expected implementation on teaching and learning methods. Similar results were reported during FGD where a teacher in School 4 said:

We are practicing what we were taught but what SQAOs brought to us was used to modify what we have. When they come with new concept I take it as a capital. In practical term the quality assurance advice can assist us to change our practices. Further teachers stated:

'During SQAOs' visit there are some areas that I was not doing well but the SQAOs advised me on how I should do better. I have corrected the way I prepare lesson plan and this has brought improvement in my teaching and learning approaches" (Focus Group Discussion: 16 th April, 2018).

One of the heads of schools from School 1 who was interviewed had this to say:

"... Some of the teachers are changing and some are not changing. Teachers from Diploma are competent than those from University, even on the way of dressing ... therefore when SQAOs visited our school they help all teachers to have common teaching and learning approaches. School QAOs' visits have added value on teaching and learning processes" (Interview: 10 th April 2018).

The Head further said:

"...I am not able to implement all the findings and recommendations on teaching and learning because there some barriers for instant you may lack number of teachers, numbers of students in relation to classrooms, proper number of teachers required to teach subjects, cooperation of parents and also family background of students ..." (Interview: 10th April 2018).

Some of the recommendations on teaching and learning methods are applicable in an environment with standard class size which is supposed to be 40 - 45 compared to the prevailing situation in schools where class size can go up to 70 students per class.

\subsection{Unintended Effects of School External Evaluation by SQAOs}

The researcher intended to assess unintended effects of SQAOs' visits in schools which might limit them from getting the true picture of the inspected schools. The challenges of occurrences of unintended effects in schools mask which consequently limit the capacity of the SQAOs to provide appropriate support and recommendation that address the weaknesses existing in schools.

The researcher developed 7 Likert items which were ranging from 1 as strongly disagree to 5 as strongly agree so as to gain understanding of the unintended effects of external evaluation through SQAOs' visits. Item means and overall means were computed from teachers' questionnaire for all three school categories as well as schools nested all school level. Results on unintended Effects that occur as a result of external school evaluation conducted during SQAOs' visit which might lead undesirable effects are presented in Table 2.

\begin{tabular}{|c|c|c|c|c|c|}
\hline \multirow[t]{2}{*}{$\mathbf{S} / \mathbf{N}$} & \multirow[t]{2}{*}{ Items Unintended Effects of School External Evaluation } & \multicolumn{4}{|c|}{ School Performance Categories } \\
\hline & & All & $\begin{array}{c}\text { Low } \\
\text { Performing }\end{array}$ & $\begin{array}{c}\text { High } \\
\text { Performing }\end{array}$ & Treatment \\
\hline 1 & $\begin{array}{l}\text { School Quality Assurance Officers visit creates anxiety in } \\
\text { school }\end{array}$ & 3.28 & 3.29 & 3.31 & 3.10 \\
\hline 2 & $\begin{array}{l}\text { Teachers do change their teaching methods in order to } \\
\text { impress SQAOs' visits }\end{array}$ & 3.22 & 3.35 & 3.21 & 3.00 \\
\hline 3 & $\begin{array}{l}\text { Logbooks are improved when teachers know that there } \\
\text { is SQAOs' visits }\end{array}$ & 3.07 & 3.35 & 2.95 & 3.00 \\
\hline 4 & $\begin{array}{l}\text { Some teachers who used not to prepare lesson plan do } \\
\text { prepare them for the purpose of SQAOs }\end{array}$ & 3.08 & 3.35 & 2.97 & 2.95 \\
\hline 5 & $\begin{array}{l}\text { School self-evaluation is conducted as external } \\
\text { evaluation requirements }\end{array}$ & 3.04 & 3.31 & 2.96 & 2.75 \\
\hline 6 & $\begin{array}{l}\text { Generally, some teachers improve their teaching in } \\
\text { order to impress SQAOs }\end{array}$ & 3.30 & 3.52 & 3.26 & 2.95 \\
\hline 7 & $\begin{array}{l}\text { Generally, some teachers make more preparation for } \\
\text { teaching in order to impress SQAOs }\end{array}$ & 3.31 & 3.54 & 3.26 & 3.05 \\
\hline & Overall Challenges & 3.19 & 3.39 & 3.13 & 2.97 \\
\hline
\end{tabular}

Table 2: Levels of Means of Unintended Effects of External Evaluation by SQAOS' Visits

Note: Level of Unintended Effects Is Very Low When $1 \leq \mathrm{M}<2$, Low When $2 \leq \mathrm{M}<3$, Moderate When $M=3$, High When $3<M \geq 4$ and Very High When $M>4$ 
Results presented in Table 2. Show that the overall level of challenges of unintended effects in schools ranged from low $(\mathrm{M}=2.97)$ in a Treatment School and high $(\mathrm{M}=3.3)$ in a low performing schools. These results further show that the levels of unintended side effects were above the moderate level $(\mathrm{M}>3)$ when all schools were nested together as well as in low performing schools. These findings presented in Table 2. further show that the trend of unintended effects in the schools were at decreasing trend from low performing, high performing and lowest in a Treatment schools both items wise and overall unintended effects, except item 1, teachers in low performing school indicated that SQAOs, visit create anxiety more in high performing schools than in low performing schools. These findings reveal that there is a possibility that the SQAOs might have not got the true picture of the low performing schools and subsequently the possibility of giving superficial recommendations to the schools.

Lowest levels of unintended side effects in a treatment school compared to those found in both low performing and high performing schools suggest that existence of self-evaluation practices might reduce occurrences of unintended side effects in schools. This might have been attributed by the fact that schools with well-established system of school selfevaluation are likely to get time to evaluate themselves before the visit of SQAOs as external evaluators which are reduce some weakness.

Analysis at the item level revealed that in both high performing schools and treatment school, items 4 and 5 had levels of challenges below the moderate mean $(\mathrm{M}<3)$. Similar trend was observed in both high performing schools for item $3(\mathrm{M}=2.95)$ on the extent to which they improved logbooks when teachers knew that there was SQAOs' visits and item 6 $(\mathrm{M}=2.95)$ in a Treatment school showing that the tendency of treatment schools to improve teaching methods in order to impress SQAOs was at low levels.

Regarding item 5, low performing schools showed high level $(\mathrm{M}=3.31)$ on the extent to which school self-evaluation was conducted as external evaluation requirements. This is very interesting because the Treatment school which had external support from the SQAOs had low level on the extent to which they conducted school self-evaluation as external evaluation requirements, in fact Treatment school had the lowest value $(\mathrm{M}=2.75)$ in this regard. This means that low performing schools might have high potential of not exhibiting ownership of school self-evaluation practices because they do it as compliance to the external requirements which might result to limited expected improvement of teaching and learning processes.

These results in Table 2 reveal that comparatively, teachers in low performing schools had high levels on the extent to which some teachers who used not to prepare lesson plan prepared lesson plans, did so for the purpose of SQAOs and also the extent to which teachers improved their teaching in order to impress SQAOs which might have resulted to SQAOs not getting the true picture of these schools. It is likely that if the SQAOs do not get the true picture of the inspected schools might give recommendations which are not relevant to the schools whose consequences may be inadequate implementation of SQAOs findings and recommendations.

Similar results were also found during interviews and focus group discussions. During interviewee with one of the heads of school, it was observed that:

"The SQAOs come as an ambush. It was okay because the school is their property. It is the best style, if you give teachers prior information you will get the wrong concept you will not get exact the situation. During the second day, teachers improved lesson preparation, this is the hypocrisy, you ambush you get what you were supposed to get. Students were informed that we had a guest, subsequently, students behaved cool, ready to answer questions but a teacher knew who was ready to answer questions. Even in history where teachers are not used to use teaching aids they prepared sketch but when the teacher learnt that SQAO was not going to assess the session, I come to learn that a teacher did not use it to teach the lesson despite that it was already prepared how it was to be used in the lesson plan (Interview: 20th April 2018).

On the other hand, teachers in one of the schools stated that SQAOs had given them information 3 days prior to their visit. However, teachers observed that the time was too short for them to make necessary preparation prior the visit. Teachers said that:

"We had sleepless nights making preparations. Prior preparations were made on the following areas scheme of work, lesson plan, teaching aids, continuous assessment records and logbooks" (Focus group Discussion: 16 April 2018).

During the interview with one of the local government Officer, it was stated that: said that:

"Some teachers do develop phobia during SQAOs' visit which is manifested as fear". However, the Officer further

"it was normal because as human being fear can manifest itself whenever someone feels to have unaccomplished task" (Interview: 23rd April 2018).

To sum up, these results may suggest that SQAOs' findings and recommendations are likely to be more reliable in high performing schools than in low performing schools because teachers in the later tend to hide the true picture of their schools. However, results further suggest that unintended effects of SQAOs' visits as an external evaluation can be minimized through the introduction of school self-evaluation mechanisms as reflected in a treatment school where the effects were consistently lower in both in all items and overall unintended effects.

\subsection{Testing of Hypothesis}

The researcher wanted to know whether or not there was significant difference in in mean levels of the implementation of findings and recommendations from SQAOs, the challenge of occurrences of unintended effects as a result of SQAOs visits. The researcher had the following null hypothesis: 


\subsubsection{Null Hypothesis $1\left(\mathrm{H}_{0}\right)$}

There is no significant difference between levels of mean scores on levels of implementation of SQAOs' findings and recommendations on Teaching and Learning Processes (improvement) in different schools.

A Kruskal Wallis Test was performed first was to tested the hypothesis on whether there was significant difference in levels of implementation of teaching and learning findings among different schools and then on whether there was significant difference of teaching and learning findings among different schools' categories. Results of Kruskal Wallis Test on levels implementation of the teaching and learning findings and recommendations among different schools when schools were all nested together are presented in Table 3.

\begin{tabular}{|c|c|c|}
\hline \multirow{2}{*}{ School Labels } & \multicolumn{2}{|c|}{ Implementation Levels (N = 166) } \\
\cline { 2 - 3 } & M & Mean Rank \\
\hline School 1 $(\mathrm{n}=20)$ & 3.30 & 73.90 \\
\hline School 2 $(\mathrm{n}=20)$ & 3.63 & 85.88 \\
\hline School 3 $(\mathrm{n}=20)$ & 4.16 & 113.63 \\
\hline School 4 $(\mathrm{n}=20)$ & 2.41 & 43.88 \\
\hline School 5 $(\mathrm{n}=18)$ & 4.08 & 98.61 \\
\hline School 6 $(\mathrm{n}=20)$ & 3.84 & 80.21 \\
\hline School 7 $(\mathrm{n}=14)$ & 3.43 & 78.89 \\
\hline School 8 $(\mathrm{n}=14)$ & 3.56 & 70.58 \\
\hline School 9 $(\mathrm{n}=20)$ & 3.34 \\
\hline Chi-Square & \multicolumn{2}{|c}{29.928} \\
\hline Df & 8 & \\
\hline Asymp. Sig. & \multicolumn{2}{|c}{} \\
\hline
\end{tabular}

Table 3: Kruskal Wallis Test for Levels of Iimplementation of the Teaching and

Learning Findings and Recommendations among Ddifferent Schools

Based on Ccumulative Mmeans

A Kruskal-Wallis Test showed that there was a statistically significant difference in levels of implementation of the teaching and learning findings and recommendations between different schools based, $\chi^{2}(8)=29.928, p=0.000$, with a mean rank score ranging from $43.88(\mathrm{M}=2.41)$ for School 4 to $105.61(\mathrm{M}=3.84)$ for School 5. These results imply that there were variations in the way schools receive and took actions in implementations of the findings and recommendations from SQAOs regarding teaching and learning process.

Further, Schools under the study were nested at school categories based on low and high performing as well as treatment schools in order to establish whether there were differences in implementation of the teaching and learning findings and recommendations between the three categories of schools. The A Kruskal-Wallis Test results are presented in Table 4.

\begin{tabular}{|c|c|c|}
\hline School Performance & Mean & Mean Rank \\
\hline High Performing Schools (N=98) & 3.61 & 89.22 \\
\hline Low Performing Schools (N=48) & 3.43 & 75.81 \\
\hline Pilot School (N=20) & 3.30 & 73.90 \\
\hline Chi-Square & \multicolumn{2}{|c|}{3.434} \\
Df & \multicolumn{2}{|c|}{2} \\
\cline { 1 - 1 } Asymp. Sig. & \multicolumn{2}{|c|}{180} \\
\hline
\end{tabular}

Table 4: Tkruskal-Wallis Test for Levels of Implementation of the

Teaching and Learning Findings and Recommendations Among Different Schools' Categories Based on Cumulative Means

A Kruskal-Wallis Test showed that there was no statistically significant difference in levels of implementation of the teaching and learning findings and recommendations between different school categories, $\chi^{2}(2)=3.434, p=0.180$ as shown in Table 4, with a mean rank score ranging from 73.9 ( $\mathrm{M=3.30)}$ for School for Treatment School to 89.22 (M=3.61) for High Performing schools.

Furthermore, the researcher was interested to know whether there was significant difference of the levels of challenges in terms of unintended effects of SQAOs' visits to schools.

A Kruskal-Wallis Test was performed first was to tested the hypothesis on whether there was significant difference in levels of Unintended effects among different schools as a result of SQAOs' visits.

\subsubsection{Null Hypothesis $2\left(\mathrm{H}_{0}\right)$}

There is no significant difference between levels of mean scores on Unintended Effects as a Result of SQAOs' Visits in different schools.

Results of Kruskal-Wallis Test on levels unintended effects of SQAOs' between different schools is summarized and presented in Table 4.7. 


\begin{tabular}{|c|c|c|}
\hline \multirow[t]{2}{*}{ Name of the School } & \multicolumn{2}{|c|}{ Unintended Effects } \\
\hline & Mean & Mean Rank \\
\hline School $1(n=20)$ & 2.97 & 73.85 \\
\hline School $2(n=20)$ & 3.39 & 90.75 \\
\hline School 3 $(\mathrm{n}=20)$ & 3.32 & 92.93 \\
\hline School $4(\mathrm{n}=20)$ & 2.23 & 41.28 \\
\hline School $5(\mathrm{n}=18)$ & 3.21 & 82.92 \\
\hline School $6(n=20)$ & 3.50 & 98.50 \\
\hline School $7(n=14)$ & 3.53 & 97.64 \\
\hline School $8(\mathrm{n}=14)$ & 3.53 & 102.43 \\
\hline School $9(\mathrm{n}=20)$ & 3.19 & 81.08 \\
\hline Chi-square & \multirow{3}{*}{\multicolumn{2}{|c|}{$\begin{array}{c}22.953 \\
8 \\
.003\end{array}$}} \\
\hline Df & & \\
\hline Asymp. Sig. & & \\
\hline
\end{tabular}

Table 5: Kruskal-Wallis Test for Challenges of Unintended Effects SQAOS' Visits between Different Schools

A Kruskal-Wallis Test showed that there was a statistically significant difference in levels of unintended effects as Challenges of External Evaluation as a result school external evaluation between different schools based, $\chi^{2}(8)=22.953, p$ $=0.003$, with a mean rank score ranging from $41.28(\mathrm{M}=2.23)$ for School 4 to $102.43(\mathrm{M}=3.53)$ for School 8. These results indicate that there were variations among schools in the extent to which schools encounter unintended effects as a result of SQAOs.

Further, Schools under the study were nested at school categories based on low and high performing as well as treatment schools in order to establish whether there were differences in mean levels of unintended effects on the implementation of findings and Recommendations on teaching and learning between different school categories. Results of Kruskal-Wallis Test presented in Table 4.8.

\begin{tabular}{|c|c|c|}
\hline \multirow{2}{*}{ Schools' Categories } & \multicolumn{2}{|c|}{ Levels of Unintended Effects } \\
\cline { 2 - 3 } & Mean & Mean Rank \\
\hline High performing & 3.13 & 81.24 \\
\hline Low Performing & 3.39 & 92.14 \\
\hline Treatment & 2.97 & 73.85 \\
\hline Chi-square & \multicolumn{2}{|c|}{2.584} \\
Df & 2 \\
\hline Asymp. Sig. & \multicolumn{2}{|c|}{.275} \\
\hline
\end{tabular}

Table 6: Kruskal-Wallis Test for Challenges of Unintended Effects SQAOS'

Visits between Different School Categories

Though that mean values show that there was highest unintended effects in low performing schools and lowest in Treatment school, a Kruskal-Wallis Test presented in Table 4.9 show that there was no statistically significant difference in levels of unintended effects of External Evaluation between different school categories, $\chi^{2}(2)=2.584, p=0.275$ as shown in, with a mean rank score ranging from $73.85(\mathrm{M}=2.97)$ in Treatment School to $81.24(\mathrm{M}=3.61)$ for High Performing schools.

\section{Conclusion of the Study}

The evidence of this study shows that there is high levels of implementation of findings and recommendations of the school's external evaluation. Means values indicate that there is higher implement of teaching and learning recommendations from the SQAOs in high performing that both low performing and Treatment schools, despite that treatment school was among the high performing schools in the City that got special support from SQAOs on how to execute self-evaluation in their school. Implementation in the Treatment school was even lower than those in low performing schools. Contrariwise, evidence of this study shows that that there are high levels of unintended effects in low performing schools than in both Treatment and high performing schools. This means that during the school visit SQAOs get true picture in Treatment and high performing schools than in a low performing schools. However, in both cases, evidence show that there is no significant difference between high and low performing schools

\section{Recommendations of the Study}

Educational policy makers should design evaluation system that integrates both external evaluation and selfevaluation based on the evidence in low performing schools and high performing schools.

\section{References}

i. Altrichter, H., \& Kemethofer, D. (2015). Does accountability pressure through school inspections promote school improvement? School Effectiveness and School Improvement, 26 (1), 32-56.

ii. Creswell, J. W. (2014) Research Design: Qualitative, Quantitative, and Mixed Methods Approaches. $4^{\text {th }}$ edition. Sage, Thousand Oakes. 
iii. De Wolf, I.F. \& Janssens, F.J.G. (2007). Effects and side effects of inspections and accountability in education: an overview of empirical studies. Oxford Review of Education, 33: 3, 379-396. DOI: 10.1080/ 03054980701366207

iv. Ehren, M. C. M. (2015). School Inspections and School Improvement; the Current Evidence Base. In Melanie C.M. Ehren (Editor): Methods and Modalities of Effective School Inspections. Springer International Publishing House, Switzerland.

v. Ehren, M.C.M., Gustafsson, J.E., Altrichter, H., Skedsmo, G., Kemethofer, D. and Huber, S.G. (2015). Comparing effects and side effects of different school inspection systems across Europe. Comparative Education, 51:3, 375400, DOI: $10.1080 / 03050068.2015 .1045769$

vi. Gaertner, H., Wurster, S., \& Pant, H. A. (2014). The effect of school inspections on school improvement. School Effectiveness and School Improvement, 25 (4), 489-508, DOI: 10.1080/ 09243453.2013.811089.

vii. Haule, M. E. (2012). The Perceptions of School Teachers and Leaders toward School Inspections in Tanzania Secondary Schools: The Case of Arusha Municipality (Master's Thesis). University of Twente, Enschede, the Netherlands.

viii. Lindgren, J. (2015). The Front and Back Stages of Swedish School Inspection: Opening the Black Box of Judgment. Scandinavian Journal of Educational Research, 59 (1), 58-76

ix. Mazibuko, S. P. (2006). The Managerial Role of the Principal in Whole-School Evaluation in the Context of Disadvantaged Schools in Kwazulu-Natal. Thesis Submitted for Doctor of Education in Education Management. University of South Africa.

x. Nayir, K. F., \& McNamara, G. (2013). The Increasingly Central Role of School Self-Evaluation in Inspection Systems across Europe: The Case of Ireland. Turkish Journal of Education, 3 (1), 48 -59.

xi. OECD. (2013). "School evaluation: From compliancy to quality", in Synergies for Better Learning: An International Perspective on Evaluation and Assessment, OECD Publishing.

xii. Opoku-Asare, N. A. A. (2006). Quality control for Effective Basic education in Ghana. Journal of Science and Technology, 26 (3), 106 - 113

xiii. Penninckx, M. (2017). Effects and side effects of school inspections: A general framework. Studies in Educational Evaluation, 52: 1-11.

xiv. URT. (2006). School Inspector's Training Manual. Dar es salaam, Tanzania, Ministry of Education and Vocational Training.

xv. URT. (2008). A Performance Audit Report on Inspection Programme for Secondary Schools in Tanzania: A report of The Controller and Auditor General of the United Republic of Tanzania. National Audit Office, Dar es Salaam. http:/ / www.nao.go.tz.

xvi. URT. (2010). Whole School Inspection checklist. Ministry of Education and Vocational Training, Dar es Salaam.

xvii. URT. (2011). School's Supervisor's Training Manual. Ministry of Education and Vocational Training, Dar es Salaam.

xviii. URT. (2016). Utendaji wa Kazi wa Idara katika Kutekeleza Majukumu ya Uthibiti Ubora wa Shule: Mada iliyowakilishwa katika mafunzo ya KKK kwa wathibiti Ubora wa shule Tanzania Bara katika vituo vya Morogoro, Kleruu, Patandi, Butimba na Mtwara, Aprili, 2016. Idara ya Uthibiti Ubora wa shule, Dar Es Salaam.

xix. Uwazi. (2009). When School Inspection doesn't Deliver. Retrieved from http// www.uwazi.org on 24/ 7/ 2014.

xx. Vanhoof, J., \& Petegem, P. V. (2007). Matching Internal and External Evaluation in an Era of Accountability and School Development: Lessons from a Flemish Perspective. Studies in Educational Evaluation, 33, 101-119.

xxi. Mcrone, T., Rudd, P., Blenkinsop, S., Wade, P., Rutt, S., \& Yeshanew, T. (2006). Impact of Section 5Inspections: Maintained schools in England (Interim Report). Available at: http:/ / files.eric.ed.gov/ fulltext/ ED502374.pdf .

xxii. MacBeath, J., \& McGlynn, A. (2005). Self-evaluation: What's in it for Schools. Taylor \& Francis e-Library, London \& New York

xxiii. Jones, K. L., \& Tymms, P. B. (2014) 'Of sted's role in promoting school improvement: the mechanisms of the school inspection system in England. Oxford Review of Education, 40 (3), 315-330. 